\title{
Quantitation of Pyridyloxobutyl DNA Adducts of Tobacco-Specific Nitrosamines in Rat Tissue DNA by High Performance Liquid Chromatography-Electrospray Ionization-Tandem Mass
}

\section{Spectrometry}

\author{
Yanbin Lao ${ }^{1,2}$, Peter W. Villalta ${ }^{2}$, Shana J. Sturla ${ }^{1,2}$, Mingyao Wang ${ }^{2}$, and Stephen S. \\ Hecht $^{2,}{ }^{*}$ \\ 1 Department of Medicinal Chemistry, University of Minnesota, Minneapolis, MN 55455
}

2 The Cancer Center, University of Minnesota, Minneapolis, MN 55455

\begin{abstract}
The tobacco-specific nitrosamines $N^{\prime}$-nitrosonornicotine (NNN, 1) and 4- (methylnitrosamino)-1-(3pyridyl)-1-butanone (NNK, 2) are potent carcinogens in rodents. Bioactivation of NNN and NNK by cytochrome $\mathrm{P} 450$ enzymes generates a pyridyloxobutylating agent $\mathbf{6}$, which alkylates DNA to produce pyridyloxobutyl (POB)-DNA adducts. POB-DNA adduct formation plays a critical role in NNN and NNK carcinogenicity in rodents. To further investigate the significance of this pathway, we developed a high performance liquid chromatography-electrospray ionization-tandem mass spectrometry (HPLC-ESI-MS/MS) method for quantitative analysis of four POB-DNA adducts with known structures. The corresponding deuterated analogs were synthesized and used as internal standards. DNA samples, spiked with internal standards, were subjected to neutral thermal hydrolysis followed by enzymatic hydrolysis. The hydrolysates were partially purified by solid phase extraction prior to HPLC-ESI-MS/MS analysis. The method was accurate and precise. Excellent sensitivity was achieved, especially for $O^{2}$-[4-(3-pyridyl)-4-oxobut-1-yl]thymidine $\left(\mathrm{O}^{2}\right.$-POB-dThd, 11) with a detection limit of 100 amol per mg DNA. DNA samples treated with different concentrations of 4(acetoxymethylnitrosamino)-1-(3-pyridyl)-1-butanone (NNKOAc, 3) were subjected to HPLC-ESIMS/MS analysis. 7-[4-(3-Pyridyl)-4-oxobut-1-yl]guanine (7-POB-Gua, 12) was the most abundant adduct, followed by $O^{6}$-[4-(3-pyridyl)-4- oxobut-1-yl]-2'-deoxyguanosine $\left(O^{6}\right.$-POB-dGuo, 8$), O^{2}$ POB-dThd, and $O^{2}$-[4-(3- pyridyl)-4-oxobut-1-yl]cytosine ( $O^{2}$-POB-Cyt, 13). Lung and liver DNA isolated from NNK-treated rats were analyzed. Consistent with the in vitro data, 7-POB-Gua was the major POB-DNA adduct formed in vivo. However, levels of $O^{6}$-POB-dGuo were the lowest of the four adducts analyzed, suggesting efficient repair of this adduct in vivo. In contrast to the other three adducts, $O^{6}$-POB-dGuo was more abundant in lung than in liver. $O^{2}$-POB-dThd appeared to be poorly repaired in vivo and its levels were comparable to those of 7-POB-Gua. The results of this study provide a sensitive HPLC-ESI-MS/MS method for comprehensive quantitation of four POB-DNA adducts, support an important role of $O^{6}$-POB-dGuo in NNK lung tumorigenicity in rats, and suggest that $O^{2}$-POB-dThd may be a useful tobacco-specific DNA biomarker for future tobacco carcinogenesis studies.
\end{abstract}

*To whom correspondence should be addressed: The Cancer Center, University of Minnesota, MMC 806, 420 Delaware St SE, Minneapolis, MN 55455, USA.ph: (612) 626-7604 fax: (612) 626-5135 e-mail: hecht002@umn.edu. 


\section{Introduction}

Tobacco-specific nitrosamines are believed to play an important role in tobacco carcinogenesis. Among these compounds, $N^{\prime}$-nitrosonornicotine $\left(\mathrm{NNN}^{1}, \mathbf{1}\right.$, Scheme 1$)$ and $4-$

(methylnitrosamino)-1-(3-pyridyl)-1-butanone (NNK, 2) are the most carcinogenic (1). NNK is a potent pulmonary carcinogen in rodents independent of the route of administration. It also induces liver, pancreas and nasal cavity tumors in rats (1). NNN causes esophageal and nasal cavity tumors in rats, and respiratory tract tumors in mice, hamsters, and mink. Oral tumors were induced when NNN mixed with NNK were swabbed in the rat oral cavity (1). NNN plus NNK have been evaluated as human carcinogens (Group 1) by the International Agency for Research on Cancer (2).

Both NNN and NNK require metabolic activation to express their carcinogenicity, and DNA adduct formation is central to their mechanisms of carcinogenesis. Metabolism and DNA adduct formation by NNN and NNK have been reviewed (1) and are briefly summarized in Scheme 1 . Two pathways catalyzed by cytochrome P450s, $\alpha$-methylene and $\alpha$-methyl hydroxylation, mainly account for NNK bioactivation. $\alpha$-Methyl hydroxylation of NNK produces intermediate $\mathbf{6}$, which reacts with $\mathrm{H}_{2} \mathrm{O}$ to give 4-hydroxy-1-(3-pyridyl)-1-butanone (HPB , 7). DNA alkylation by 6 produces pyridyloxobutyl (POB)-DNA adducts. 4(Acetoxymethylnitrosamino)-1-(3-pyridyl)-1-butanone (NNKOAc, 3), a regiochemically activated form of NNK, has been extensively used in studies of POB-DNA adduct formation. Upon hydrolysis by esterase, NNKOAc releases 6 which alkylates DNA. Similarly, NNN can be metabolically activated by cytochrome P450-catalyzed 5'-and 2'-hydroxylation (Scheme 1) (1). The same intermediate 6 produced by NNN $2^{\prime}$-hydroxylation gives rise to POB-DNA adducts. The properties of one adduct, $O^{6}$-[4-(3-pyridyl)-4-oxobut-1-yl]-2'-deoxyguanosine $\left(O^{6}\right.$-POB-dGuo, 8$)$, have been studied previously (3-5). More recently, three new POB-DNA adducts, 7-[4-(3-pyridyl)-4-oxobut-1-yl]-2'-deoxyguanosine (7-POB-dGuo, 9) (6), $O^{2}$-[4- (3pyridyl)-4-oxobut-1-yl]-2'-deoxycytidine ( $O^{2}$-POB-dCyd, 10) (7) and $O^{2}$-[4-(3- pyridyl)-4oxobut-1-yl]thymidine ( $O^{2}$-POB-dThd, 11) (7), have been identified. Upon neutral thermal hydrolysis (heating at $100{ }^{\circ} \mathrm{C}$ for $1 \mathrm{~h}$ ) of DNA containing 7-POB-dGuo and $O^{2}$-POB-dCyd, HPB (7) is released from these adducts with the formation of dGuo and dCyd respectively (Scheme 1). Under the same conditions, the stable adducts, 7-[4- (3-pyridyl)-4-oxobut-1-yl] guanine (7-POB-Gua, 12) and $O^{2}$-[4-(3-pyridyl)-4-oxobut-1- yl]cytosine $\left(O^{2}\right.$-POB-Cyt, 13) are produced with the loss of 2'-deoxyribose (Scheme 1) $(6,7)$. The formation of POB-DNA adducts is believed to be an important mechanism for NNN and NNK carcinogenesis in rodents $(8-12)$, and likely in smokers $(13,14)$.

To further explore the mechanistic role of this bioactivation pathway, a sensitive analytical method is needed to monitor the formation, persistence, and repair of POB-DNA adducts in vivo. Thomson et al developed a liquid chromatography -electrospray ionization -tandem mass spectrometry (LC-ESI-MS/MS) method for quantitation of $O^{6}$-POB-dGuo (15). The limit of detection was $1 \mathrm{fmol}$ of standard. Recently, we reported the relative levels of 7-POB-Gua, $O^{6}$-POB-dGuo, $O^{2}$-POB-dThd, and $O^{2}$-POB-Cyt in reactions of calf thymus DNA with NNKOAc (16). However, the lack of stable isotope-labeled internal standards limited the application of that method. In this study, using all four deuterated internal standards, we developed and validated an HPLC-ESI-MS/MS method for quantitative analysis of the above four adducts. The current method is highly sensitive, accurate, and precise. It has been applied to quantify POB-DNA adducts in liver and lung of NNK-treated rats. 


\section{Experimental Procedures}

\section{Caution}

NNK and NNKOAc are carcinogenic. They should be handled in a well-ventilated hood with extreme care, and with personal protective equipment.

\section{Chemicals}

$O^{6}$-POB-dGuo, $O^{2}$-POB-dThd, 7-POB-Gua, $O^{2}$-POB-Cyt, and [pyridine-- 4 ] 7-POB-Gua ([pyridine-D $\left.\mathbf{D}_{4}\right]_{12}$ ) were prepared as described (16). All standards had purities of at least $99 \%$ (HPLC-UV). The isotopic purity of [pyridine-D 4 ]7-POB-Gua was estimated as 98 atom\%D based on the isotopic purity of the starting material,. [pyridine- $\mathrm{D}_{4}$ ]ethyl nicotinate, which was purchased from Cambridge Isotope Laboratories (Andover, MA). Micrococcal nuclease (LS004797, $15 \mathrm{kU}$ ) and phosphodiesterase II (LS003603, $10 \mathrm{U}$ ) were obtained from Worthington Biochemical Corporation (Lakewood, NJ). Alkaline phosphatase (567752, $30 \mathrm{U} /$ $\mu \mathrm{L}$ ) was purchased from Roche Molecular Biochemicals (Indianapolis, IN). Porcine liver esterase (E-2884, $1.84 \mathrm{U} / \mu \mathrm{L}$ ) was obtained from Sigma-Aldrich Chemical Co. (Milwaukee, WI). All other chemicals and solvents were acquired from Sigma-Aldrich or Fisher Scientific (Fairlawn, NJ).

\section{NMR and MS}

Qualitative MS was performed on a Finnigan LCQ Deca instrument (Finnigan MAT/ Thermoquest, San Jose, CA) or on an Agilent 1100 LC/MSD ion trap instrument (Agilent Technologies, Inc. Wilmington, DE) in positive-ion mode for characterization of deuterated standards. The development, validation, and application of the quantitative method was conducted on either a Finnigan TSQ Quantum Ultra AM or a TSQ Quantum Discovery Max (Thermo Electron, San Jose, CA) instrument coupled with an Agilent 1100 series capillary HPLC system. NMR spectra were acquired on a Varian Inova $500 \mathrm{MHz}$ or $600 \mathrm{MHz}$ instrument (Varian, Inc., Palo Alto, CA).

\section{HPLC Analysis}

HPLC was carried out with Waters Associates (Medford, MA) systems equipped with a Shimadzu SPD-10A UV-Vis detector (Shimadzu Scientific Instruments, Columbia, MD) for systems 1 and 4, or a model 996 photodiode array detector for systems 2 and 3. UV detection was at $254 \mathrm{~nm}$. Columns and solvent elution systems were as follows. System 1 was a $250 \mathrm{~mm}$ $\times 21.2 \mathrm{~mm}$ Luna $5 \mu \mathrm{m} \mathrm{C18} \mathrm{(2)} \mathrm{column} \mathrm{(Phenomenex,} \mathrm{Torrance,} \mathrm{CA)} \mathrm{with} \mathrm{isocratic} \mathrm{elution} \mathrm{by}$ $5 \% \mathrm{MeOH}$ in $\mathrm{H}_{2} \mathrm{O}$ for $5 \mathrm{~min}$ and then a gradient from 5 to $35 \% \mathrm{MeOH}$ over $20 \mathrm{~min}$, followed by 35 to $50 \% \mathrm{MeOH}$ over a period of $20 \mathrm{~min}$ at a rate of $7.0 \mathrm{~mL} / \mathrm{min}$. This system was used for purification of [pyridine- $\left.\mathrm{D}_{4}\right] O^{2}$-POB-dThd ([pyridine- $\left.\mathbf{D}_{4}\right] \mathbf{1 1}$ ). System 2 was a $250 \mathrm{~mm} \times$ $3.0 \mathrm{~mm}$ Luna $5 \mu \mathrm{m} \mathrm{C} 18$ (2) column (Phenomenex) with isocratic elution by $5 \% \mathrm{MeOH}$ in 40 $\mathrm{mM}$ ammonium acetate buffer ( $\mathrm{pH}$ 6.8) for $10 \mathrm{~min}$, then a gradient from 5 to $25 \% \mathrm{MeOH}$ over the course of $60 \mathrm{~min}$, followed by 25 to $50 \% \mathrm{MeOH}$ for an additional $10 \mathrm{~min}$, and then to $5 \%$ $\mathrm{MeOH}$ in $5 \mathrm{~min}$ at a flow rate of $0.5 \mathrm{~mL} / \mathrm{min}$. In system 3, we used the same column and flow rate as in system 2 . However, the gradient was changed to initial isocratic elution by $5 \%$ acetonitrile in $40 \mathrm{mM}$ ammonium acetate ( $\mathrm{pH} \mathrm{6.8)}$ ) for $10 \mathrm{~min}$, then 5 to $25 \%$ acetonitrile in 40 $\mathrm{min}$, followed by a return to $5 \%$ acetonitrile in $2 \mathrm{~min}$. Systems 2 and 3 were used for the first and second purification of [pyridine- $\left.\mathrm{D}_{4}\right] O^{2}$-POB-Cyt ([pyridine-- $\left.\mathbf{D}_{\mathbf{4}}\right] \mathbf{1 3}$ ), respectively. System 4 consisted of a $250 \mathrm{~mm} \times 4.6 \mathrm{~mm}$ Luna $5 \mu \mathrm{m} \mathrm{C18} \mathrm{(2)} \mathrm{column} \mathrm{with} \mathrm{a} \mathrm{gradient} \mathrm{from} 5$ to $40 \%$ $\mathrm{MeOH}$ in $\mathrm{H}_{2} \mathrm{O}$ over a period of $35 \mathrm{~min}$, followed by 40 to $100 \% \mathrm{MeOH}$ in 5 min, then held at $100 \% \mathrm{MeOH}$ for 10 min before going back to $5 \% \mathrm{MeOH}$ in $10 \mathrm{~min}$ at a flow rate of $0.7 \mathrm{~mL} /$ $\mathrm{min}$. This system was used for quantitation of dGuo in enzymatic hydrolysates of DNA samples. 


\section{Synthesis of Deuterated Standards}

[Pyridine- $\left.\mathrm{D}_{4}\right] O^{6}$-[4-(3-pyridyl)-4-oxobut-1-yl]-2'-deoxyguanosine ([Pyridine- $\left.\mathrm{D}_{4}\right] O^{6}$ POB-dGuo, [pyridine- $\mathbf{D}_{\mathbf{4}}$ ] 8 ) was synthesized based on a previously published method for $O^{6}$-POB-dGuo $(3,17)$. [Pyridine- $\mathrm{D}_{4}$ ] 3-pyridine carboxaldehyde (16) was prepared from commercially available [pyridine- $\mathrm{D}_{4}$ ] thyl nicotinate (14) (18). Compound $\mathbf{1 4}(2 \mathrm{~g}, 13 \mathrm{mmol})$ in $\mathrm{MeOH}(10 \mathrm{~mL})$ was added dropwise to a solution of $\mathrm{NaBH}_{4}(4.9 \mathrm{~g}, 130 \mathrm{mmol})$ in $\mathrm{MeOH}$ $(20 \mathrm{~mL})$. The reaction mixture was heated under reflux for $2 \mathrm{~h}$. Water $(30 \mathrm{~mL})$ was added and the $\mathrm{MeOH}$ was evaporated. The mixture was extracted with EtOAc $(3 \times 30 \mathrm{~mL})$. The organic layers were washed with $1 \mathrm{M} \mathrm{HCl}(2 \times 50 \mathrm{~mL})$. Then the aqueous solution was adjusted to $\mathrm{pH}$ 7 with $10 \mathrm{~N} \mathrm{NaOH}$, and extracted with EtOAc $(5 \times 100 \mathrm{~mL})$. The EtOAc layers were combined, dried $\left(\mathrm{Na}_{2} \mathrm{SO}_{4}\right)$, and evaporated to dryness to give [pyridine- $\mathrm{D}_{4}$ ] 3 -hydroxymethylpyridine $(\mathbf{1 5}, 1.0 \mathrm{~g}, 8.85 \mathrm{mmol}, 68 \%)$. A solution of $15(500 \mathrm{mg}, 4.42 \mathrm{mmol})$ in $10 \mathrm{~mL}$ of anhydrous $\mathrm{CH}_{2} \mathrm{Cl}_{2}$ was added to a mixture of pyridinium chlorochromate (PCC, $1.9 \mathrm{~g}, 8.82 \mathrm{mmol}$ ) in 10 $\mathrm{mL}$ of $\mathrm{CH}_{2} \mathrm{Cl}_{2}$. The mixture was stirred under $\mathrm{N}_{2}$ at room temperature for $1 \mathrm{~h}$. Ether $(50 \mathrm{~mL})$ was added, the mixture was stirred for an additional $30 \mathrm{~min}$ at room temperature, and then loaded onto a short column of Florisil. [Pyridine- $\mathrm{D}_{4}$ ]3-pyridine carboxaldehyde $(\mathbf{1 6}, 110 \mathrm{mg}$, $1 \mathrm{mmol}, 22 \%)$ was eluted from the column with EtOAc. [Pyridine- $\left.\mathrm{D}_{4}\right] O^{6}$-POB-dGuo (6.96 $\mathrm{mg}, 16.65 \mu \mathrm{mol})$ was then synthesized, according to the published procedure for $O^{6}$-POBdGuo $(3,17)$. Purity: at least $99 \%$ (HPLC-UV), isotopic purity: 98 atom\%D, ${ }^{1} \mathrm{H}-\mathrm{NMR}$ $\left(\mathrm{CDCl}_{3}\right): \delta 7.61(\mathrm{~s}, 1 \mathrm{H}, \mathrm{H}-8), 6.21\left(\mathrm{dd}, J=5.4,9.6 \mathrm{~Hz}, 1 \mathrm{H}, 1^{\prime} \mathrm{H}\right), 4.89\left(\mathrm{br}, 2 \mathrm{H}, 2-\mathrm{NH}_{2}\right), 4.74(\mathrm{~d}$, $\left.J=4.8 \mathrm{~Hz}, 1 \mathrm{H}, 3^{\prime} \mathrm{H}\right), 4.59\left(\mathrm{t}, J=6.0 \mathrm{~Hz}, 2 \mathrm{H}, \mathrm{H}_{\mathrm{A}}\right), 4.18\left(\mathrm{br}, 1 \mathrm{H}, 4^{\prime} \mathrm{H}\right), 3.94\left(\mathrm{~d}, J=11.4 \mathrm{~Hz}, 1 \mathrm{H}, 5^{\prime}\right.$ Ha), $3.74\left(\mathrm{~d}, J=12.0 \mathrm{~Hz}, 1 \mathrm{H}, 5^{\prime} \mathrm{Hb}\right), 3.22\left(\mathrm{t}, J=7.2 \mathrm{~Hz}, 2 \mathrm{H}, \mathrm{H}_{\mathrm{C}}\right), 3.00\left(\mathrm{~m}, 1 \mathrm{H}, 2^{\prime} \mathrm{Ha}\right), 2.29$ (m, $\left.2 \mathrm{H}, \mathrm{H}_{\mathrm{B}}\right), 2.23\left(\mathrm{~m}, 1 \mathrm{H}, 2^{\prime} \mathrm{Hb}\right), \mathrm{UV}\left(\mathrm{MeOH} / \mathrm{pH} 6.8\right.$ buffer): $\lambda_{\max }(\mathrm{nm}) 277.0,235.8,210.1$, positive ESI-MS $m / z 419[\mathrm{M}+\mathrm{H}]^{+}, \mathrm{MS} / \mathrm{MS}$ of $\mathrm{m} / \mathrm{z} 419: \mathrm{m} / z 303[\mathrm{M}-116+\mathrm{H}]^{+}, \mathrm{m} / z 268[\mathrm{M}-$ [pyridine- $\left.\left.\mathrm{D}_{4}\right] \mathrm{POB}+\mathrm{H}\right]^{+}, m / z 152[\mathrm{Gua}+\mathrm{H}]^{+}$and [[pyridine- $\left.\left.\mathrm{D}_{4}\right] \mathrm{POB}\right]^{+}$.

\section{[Pyridine- $\left.\mathrm{D}_{4}\right] O^{2}-[4-(3-p y r i d y l)-4-o x o b u t-1-y l]$ thymidine ([Pyridine- $\left.\mathrm{D}_{4}\right] O^{2}-\mathrm{POB}-\mathrm{dThd}$, [pyridine- $\left.\mathrm{D}_{4}\right] 11$ )}

Thymidine-5'-toluenesulfonate ester (62 $\mathrm{mg}, 0.15 \mathrm{mmol})(16)$ was allowed to react with [pyridine- $\mathrm{D}_{4}$ ] HPB (464 mg, $\left.2.74 \mathrm{mmol}\right)(16)$ in the presence of 1,8-diazobicyclo[5.4.0] undec-7-ene ( $332 \mathrm{mg}, 2.18 \mathrm{mmol}$ ), followed by HPLC purification (system 1) to give [pyridine$\left.\mathrm{D}_{4}\right] O^{2}$-POB-dThd $(597 \mu \mathrm{g}, 1.52 \mu \mathrm{mol}, 1 \%)$. Purity: at least $99 \%$ (HPLC-UV), isotopic purity: 98 atom\%D, ${ }^{1} \mathrm{H}-\mathrm{NMR}\left(\mathrm{DMSO}-d_{6}\right): \delta 7.82(\mathrm{~s}, 1 \mathrm{H}, 6 \mathrm{H}), 6.21\left(\mathrm{t}, J=6.0 \mathrm{~Hz}, 1 \mathrm{H}, 1^{\prime} \mathrm{H}\right), 4.35(\mathrm{t}$, $\left.J=6.0 \mathrm{~Hz}, 2 \mathrm{H}, \mathrm{H}_{\mathrm{A}}\right), 4.23\left(\mathrm{br}, 1 \mathrm{H}, 3^{\prime} \mathrm{H}\right), 3.77\left(\mathrm{br}, 1 \mathrm{H}, 4^{\prime} \mathrm{H}\right), 3.60\left(\mathrm{dd}, J=3.0,12.0 \mathrm{~Hz}, 1 \mathrm{H}, 5^{\prime} \mathrm{Ha}\right)$, $3.54\left(\mathrm{dd}, J=3.0,12.0 \mathrm{~Hz}, 1 \mathrm{H}, 5^{\prime} \mathrm{Hb}\right), 3.16\left(\mathrm{br}, 2 \mathrm{H}, \mathrm{H}_{\mathrm{C}}\right), 2.16\left(\mathrm{~m}, 2 \mathrm{H}, 2^{\prime} \mathrm{H}\right), 2.07\left(\mathrm{~m}, 2 \mathrm{H}, \mathrm{H}_{\mathrm{B}}\right)$, $1.78\left(\mathrm{~s}, 3 \mathrm{H}, 5-\mathrm{CH}_{3}\right), \mathrm{UV}$ (acetonitrile/ $\mathrm{H}_{2} \mathrm{O}$ ): $\lambda_{\max }(\mathrm{nm}) 258.1,231.1$, positive ESI-MS $\mathrm{m} / z 394$ $[\mathrm{M}+\mathrm{H}]^{+}, \mathrm{MS} / \mathrm{MS}$ of $m / z 394: \mathrm{m} / z 278[\mathrm{M}-116+\mathrm{H}]^{+}, \mathrm{m} / z 152$ [[pyridine-- $\left.\left.{ }_{4}\right] \mathrm{POB}\right]^{+}$.

\section{[Pyridine- $\left.\mathrm{D}_{4}\right] O^{2}-[4-(3-p y r i d y l)-4-o x o b u t-1-y l] c y t o s i n e$ ([Pyridine- $\left.\mathrm{D}_{4}\right] O^{2}-\mathrm{POB}-\mathrm{Cyt}$, [pyridine- $\left.\left.D_{4}\right] 13\right)$}

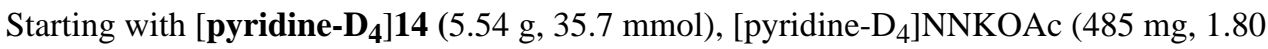
mmol) was prepared using the synthetic method for NNKOAc (3) (19). [Pyridine-- $\mathrm{D}_{4}$ ] NNKOAc (138 mg, $0.51 \mathrm{mmol})$ was then incubated with dCyd $(26 \mathrm{mg}, 0.115 \mathrm{mmol})$ in the presence of porcine liver esterase $(170 \mu \mathrm{L})$ at $37{ }^{\circ} \mathrm{C}$ for $1 \mathrm{~h}$, followed by heating at $100{ }^{\circ} \mathrm{C}$ for $1 \mathrm{~h}$. [Pyridine- $\left.\mathrm{D}_{4}\right] O^{2}$-POB-Cyt was purified by HPLC using systems 2 and 3 sequentially. The same procedure was repeated four times to give $17.8 \mu \mathrm{g}(0.068 \mu \mathrm{mol}, 0.01 \%)$ of [pyridine$\left.\mathrm{D}_{4}\right] O^{2}$-POB-Cyt. Purity: at least $99 \%$ (HPLC-UV), isotopic purity: 98 atom $\% \mathrm{D},{ }^{1} \mathrm{H}-\mathrm{NMR}$ (DMSO- $\left.d_{6}\right): \delta 7.81(\mathrm{~d}, J=5.4 \mathrm{~Hz}, 1 \mathrm{H}, 6 \mathrm{H}), 6.79\left(\mathrm{br}, 2 \mathrm{H}, 4-\mathrm{NH}_{2}\right), 6.04(\mathrm{~d}, J=6.0 \mathrm{~Hz}, 1 \mathrm{H}, 5 \mathrm{H})$, $4.20\left(\mathrm{t}, J=6.6 \mathrm{~Hz}, 2 \mathrm{H}, \mathrm{H}_{\mathrm{A}}\right), 3.19\left(\mathrm{t}, J=6.6 \mathrm{~Hz}, 2 \mathrm{H}, \mathrm{H}_{\mathrm{C}}\right), 2.01\left(\mathrm{~m}, 2 \mathrm{H}, \mathrm{H}_{\mathrm{B}}\right), \mathrm{UV}$ (acetonitrile/pH 6.8 buffer): $\lambda_{\max }(\mathrm{nm}) 268.8,227.6$, positive ESI-MS $\mathrm{m} / \mathrm{z} 263[\mathrm{M}+\mathrm{H}]^{+}$, MS/MS of $\mathrm{m} / z 263$ : $\mathrm{m} / z, 152\left[\left[\text { pyridine- } \mathrm{D}_{4}\right] \mathrm{POB}\right]^{+}, \mathrm{m} / z, 112[\mathrm{Cyt}+\mathrm{H}]^{+}$. 
A stock solution of [pyridine- $\left.\mathrm{D}_{4}\right] O^{6}-\mathrm{POB}-\mathrm{dGuo}(1.67 \mathrm{nmol} / \mu \mathrm{L})$ was prepared gravimetrically, and stock solutions of [pyridine- $\left.\mathrm{D}_{4}\right] O^{2}$-POB-dThd $(304 \mathrm{pmol} / \mu \mathrm{L})$ and $\left[\right.$ pyridine- $\left.\mathrm{D}_{4}\right] O^{2}$-POBCyt $(13.6 \mathrm{pmol} / \mu \mathrm{L})$ were prepared by NMR standardization with toluene as internal standard, as previously described (16).

\section{In Vitro DNA Samples}

Two NNKOAc-treated calf thymus DNA samples, ctDNA-A and ctDNA-B, were obtained from the previous study (16) and used for development and validation of the method. Briefly, calf thymus DNA ( $20 \mathrm{mg}, 70 \mu \mathrm{mol}$ ) was incubated with NNKOAc (for ctDNA-A: $10 \mathrm{mg}, 40$ $\mu \mathrm{mol}$; for ctDNA-B: $20 \mathrm{mg}, 80 \mu \mathrm{mol})$ in the presence of porcine liver esterase $(0.5-1.0 \mu \mathrm{L}$ per $\mathrm{mg}$ NNKOAc) in $0.1 \mathrm{M}$ phosphate buffer $(10 \mathrm{~mL}, \mathrm{pH} 7.0)$ at $37^{\circ} \mathrm{C}$ for $1.5 \mathrm{~h}$. The incubation mixture was washed with equal volumes of $\mathrm{CHCl}_{3}$ /isoamyl alcohol (24:1) and ethyl acetate sequentially. The DNA was precipitated by adding cold ethanol, washed with $70 \%$ ethanol and ethanol sequentially, dried under a stream of $\mathrm{N}_{2}$, and stored at $-20{ }^{\circ} \mathrm{C}$ until analysis.

\section{In Vivo DNA Samples}

These were isolated from liver and lung of NNK-treated male F344 rats. The animals were purchased at age 5-6 weeks from Charles River (Wilmington, MA). They were housed under standard conditions and maintained on NIH-07 diet (Harlan, Madison, WI) in the Research Animal Resources facility of the University of Minnesota. Groups of 5 rats (225-275 g) were treated with saline $(0.4 \mathrm{~mL}$ )(control group), $5.2 \mathrm{mg}(0.025 \mathrm{mmol}) \mathrm{NNK} / \mathrm{kg}$ body weight in 0.4 $\mathrm{mL}$ saline (low dose group), or $20.7 \mathrm{mg}(0.1 \mathrm{mmol}) \mathrm{NNK} / \mathrm{kg}$ body weight in $0.4 \mathrm{~mL}$ saline (high dose group), once daily for four consecutive days by s.c. injection. Four $\mathrm{h}$ after the final dose, the rats were killed by $\mathrm{CO}_{2}$ overdose. Liver and lung were harvested, and DNA was isolated by following the "DNA Purification from $1 \mathrm{~g}$ Animal Tissue" protocol from Gentra Systems (Minneapolis, MN) with modifications (20) and stored at $-20^{\circ} \mathrm{C}$ until analysis.

\section{HPLC-ESI-MS/MS Analysis}

The procedure for enzymatic hydrolysis of DNA was previously described (15). In brief, DNA samples (about $1 \mathrm{mg}$ for in vitro and $0.5 \mathrm{mg}$ for in vivo) were dissolved in $10 \mathrm{mM}$ sodium succinate $/ 5 \mathrm{mM} \mathrm{CaCl}_{2}$ buffer ( $\left.1 \mathrm{~mL}, \mathrm{pH} 7.0\right)$, to which the 4 deuterated internal standards had been added. The mixture was heated at $100{ }^{\circ} \mathrm{C}$ for $30 \mathrm{~min}$, then cooled to room temperature. Micrococcal nuclease $(75 \mathrm{U})$ and phosphodiesterase II $(450 \mathrm{mU})$ were added, and the mixture was incubated at $37^{\circ} \mathrm{C}$. After $6 \mathrm{~h}$, alkaline phosphatase $(150 \mathrm{U})$ was added, followed by incubation at $37{ }^{\circ} \mathrm{C}$ overnight. An aliquot $(10 \mu \mathrm{L})$ of the enzymatic hydrolysate was saved for quantitation of dGuo (HPLC system 4), and the remainder was loaded on a Strata-X cartridge (33 $\mu \mathrm{m}, \mathrm{mg} / \mathrm{mL}, 1 \mathrm{~mL}$, Phenomenex). The cartridge was sequentially eluted with $2 \times 1 \mathrm{~mL}$ $\mathrm{H}_{2} \mathrm{O}, 1 \mathrm{~mL} 10 \%$ aqueous $\mathrm{MeOH}$, and $2 \times 1 \mathrm{~mL} \mathrm{MeOH}$. The $\mathrm{MeOH}$ fraction was collected in a 4-mL silanized vial (ChromTech, Minneapolis, $\mathrm{MN}$ ) and dried under reduced pressure using a centrifugal vacuum evaporator (Savant SpeedVac ${ }^{\circ}$, Thermo Eclectron, San Jose, CA). The residue was then transferred with $2 \times 100 \mu \mathrm{L} \mathrm{MeOH}$ to a silanized autosampler vial with an infused $300-\mu \mathrm{L}$ inset (ChromTech), and dried again under vacuum. Water $(15 \mu \mathrm{L})$ was added to the MS vial and the solution was sonicated for $10 \mathrm{~min}$, then vortexed and centrifuged.

Eight $\mu \mathrm{L}$ of the sample per injection was introduced with an autosampler into the ESI source using a $150 \mathrm{~mm} \times 0.5 \mathrm{~mm}$ Zorbax SB C18 column (Agilent) with a gradient from 0 to $25 \%$ acetonitrile in $15 \mathrm{mM}$ ammonium acetate over a period of $29 \mathrm{~min}$, then 25 to $75 \%$ acetonitrile for $5 \mathrm{~min}$, then $75 \%$ acetonitrile for $5 \mathrm{~min}$, then returning to $0 \%$ acetonitrile in $5 \mathrm{~min}$, at a flow rate of $15 \mu \mathrm{L} / \mathrm{min}$. The column was operated at $25^{\circ} \mathrm{C}$. The first 10 min eluant was directed to waste, and the $10-40 \mathrm{~min}$ fractions were diverted to the ESI source. The retention times of the POB-DNA adducts in this HPLC system were: $O^{6}$-POB-dGuo, $27.5 \mathrm{~min} ; O^{2}$-POB-dThd, $24.0 \mathrm{~min}$; 7-POB-Gua, $20.7 \mathrm{~min}$; and $O^{2}$-POB-Cyt, $27.3 \mathrm{~min}$. 
The ESI source was operated in the positive-ion mode. The POB-DNA adducts, along with their deuterated standards, were monitored by selected reaction monitoring (SRM). The ion transitions were: $O^{6}$-POB-dGuo, $\mathrm{m} / z 415.1[\mathrm{M}+1]^{+}$to $\mathrm{m} / z$ 148.1 [POB ${ }^{+}$; [pyridine- $\left.\mathrm{D}_{4}\right] O^{6}$ POB-dGuo, $m / z 419.1[\mathrm{M}+1]^{+}$to $m / z 152.1$ ([pyridine- $\left.\left.\left.\mathrm{D}_{4}\right] \mathrm{POB}\right]\right)^{+}$and $[\mathrm{Gua}+\mathrm{H}]^{+} ; O^{2}-\mathrm{POB}-$ dThd, $m / z 390.1[\mathrm{M}+1]^{+}$to $m / z$ 148.1 [POB] $]^{+}$; [pyridine- $\left.\mathrm{D}_{4}\right] O^{2}$-POB-dThd, $m / z 394.1[\mathrm{M}+$ $1]^{+}$to $m / z 152.1\left(\right.$ (pyridine- $\left.\left.\left.\mathrm{D}_{4}\right] \mathrm{POB}\right]\right)^{+} ; 7$ - POB-Gua, $\mathrm{m} / z 299.1[\mathrm{M}+1]^{+}$to $\mathrm{m} / z 148.1$ [POB] $^{+}$; [pyridine- $\mathrm{D}_{4}$ ]7-POB-Gua, $m / z 303.1[\mathrm{M}+1]^{+}$to $m / z 152.1$ ([pyridine-D $_{4}$ ]POB]) ${ }^{+}$ and $[\mathrm{Gua}+\mathrm{H}]^{+} ; \mathrm{O}^{2}$-POB-Cyt, $\mathrm{m} / z 259.1[\mathrm{M}+1]^{+}$to $\mathrm{m} / z 148.1$ [POB] $]^{+}$; [pyridine-D 4$]^{2}-\mathrm{POB}-$ Cyt, $m / z 263.1[\mathrm{M}+1]^{+}$to $\mathrm{m} / z 152.1$ ([pyridine-D 4$\left.\left.] \mathrm{POB}\right]\right)^{+}$. When the HPLC-ESI-MS/MS method was being validated for each POB-DNA adduct, the MS parameters were optimized to achieve the maximum signal for the adduct by tuning the instrument with the corresponding deuterated standard. For analysis of in vitro and in vivo DNA samples, the MS parameters were set as follows: spray voltage, $4 \mathrm{kV}$; sheath gas pressure, 30 ; capillary temperature, $200{ }^{\circ} \mathrm{C}$; collision energy, $20 \mathrm{~V}$; scan width, $0.5 \mathrm{amu}$; scan time, $0.2 \mathrm{~s}$, Q1 peak width, $0.7 \mathrm{amu}$; Q3 peak width, $0.7 \mathrm{amu}$; Q2 gas pressure, $1.0 \mathrm{mTorr}$; source CID, $10 \mathrm{~V}$; tube lens offset, $94 \mathrm{~V}$. MS/MS data were acquired and processed by Xcaliber software version 1.4 (Thermo Electron). The amount of each POB-DNA adduct was determined by comparing the MS peak area ratio of each adduct to its deuterated standard with a calibration curve. Calibration standards were prepared by spiking different amounts of each adduct with a constant amount of the corresponding internal standard in $\mathrm{H}_{2} \mathrm{O}$, and then analyzed by LC-MS/MS without undergoing the sample preparation procedure described above. The calibration curves were constructed by plotting concentration ratio versus MS peak area ratio of each adduct to its deuterated standard. The adduct levels were expressed as pmol (for in vitro samples) or fmol (for in vivo samples) per $\mu$ mol dGuo.

\section{Results}

We report here the preparation of three deuterated internal standards, [pyridine- $\left.\mathrm{D}_{4}\right] O^{6}$-POBdGuo, [pyridine- $\left.\mathrm{D}_{4}\right] O^{2}-\mathrm{POB}-\mathrm{dThd}$, and [pyridine- $\left.\mathrm{D}_{4}\right] O^{2}$-POB-Cyt, as well as the development and validation of a sensitive HPLC-ESI-MS/MS method for quantitative analysis of four stable POB-DNA adducts. The method was applied for analysis of lung and liver DNA isolated from NNK-treated F344 rats.

\section{Synthesis and calibration}

[Pyridine- $\left.\mathrm{D}_{4}\right] O^{6}$-POB-dGuo was prepared as reported previously for $O^{6}$-POB-dGuo $(17,18)$. [Pyridine- $\left.\mathrm{D}_{4}\right] O^{2}$-POB-dThd and [pyridine- $\left.\mathrm{D}_{4}\right] O^{2}$-POB-Cyt were synthesized as described for $O^{2}$-POB-dThd and $O^{2}$-POB-Cyt (16). The structures of these deuterated standards were established by UV, MS and ${ }^{1} \mathrm{H}-\mathrm{NMR}$. The deuterated analogs had the same UV spectra as the non-deuterated adducts, the expected four-unit increases in mass spectra, and lack of pyridyl protons in the ${ }^{1} \mathrm{H}-\mathrm{NMR}$ spectra. Calibration curves were constructed by analysis of calibration standards prepared by adding a constant amount of each deuterated standard to increasing concentrations of the non-deuterated standards, and plotting concentration ratios versus MS peak area ratios of analyte/internal standard. Each adduct was detected by SRM for $[\mathrm{M}+1]^{+}$ $\rightarrow[\mathrm{POB}]^{+}$. The plots showed excellent linearity (see Supporting Information SFigure 1A-D).

\section{Method development}

The HPLC-ESI-MS/MS method was developed on the basis of our previous study, with modifications (16). In this method, the base adducts 7-POB-Gua and $O^{2}$-POB-Cyt, which resulted from unstable adducts bearing quaternary nitrogens (Scheme 1), were released from the DNA backbone upon neutral thermal hydrolysis. Further enzymatic hydrolysis produced the nucleoside adducts $O^{2}$-POB-dThd and $O^{6}$-POB-dGuo. The DNA enzymatic hydrolysis procedure was further investigated. When calf thymus DNA was digested by a combination 
of DNAse I, phosphodiesterase I and alkaline phosphatase, two significant interfering peaks eluting at the same retention times as $O^{6}$-POB-dGuo and $O^{2}$-POB-Cyt were observed, but there were no interferences for $O^{2}$-POB-dThd and 7-POB-Gua (data not shown). When a different procedure was used, consisting of micrococcal nuclease, phosphodiesterase II and alkaline phosphatase, the levels of both interfering peaks were lowered to background such that quantitation of $O^{6}$-POB-dGuo and $O^{2}$-POB-Cyt was feasible. Another modification was the use of a different ion transition for SRM. In previous studies $(15,16), O^{6}$-POB-dGuo was quantified by SRM for $m / z 415.1[\mathrm{M}+1]^{+} \rightarrow m / z 299.1[\mathrm{BH}]^{+}$. However, the MS response increased 5 times when the ion transition $m / z 415.1[\mathrm{M}+1]^{+} \rightarrow \mathrm{m} / z 148.1[\mathrm{POB}]^{+}$was used. Similarly, the same modification achieved 6 times higher MS response for $O^{2}$-POB-dThd.

\section{Quantitation of POB-DNA adducts in calf thymus DNA treated with NNKOAC}

Levels of POB-DNA adducts in ctDNA-A and ctDNA-B were quantified by the HPLC-ESIMS/MS method (Figure 1, also see Table 1 in Supporting Information). In each of these NNKOAc-treated DNA samples, levels of adducts followed the same order: 7-POB-Gua > $O^{6}$-POB-dGuo $>O^{2}$-POB-dThd $>O^{2}$-POB-Cyt. 7-POB-Gua accounted for $46 \%$ of total POB adducts in ctDNA-A and $43 \%$ in ctDNA-B. The corresponding values for the other adducts were (\% in ctDNA-A, $\%$ in ctDNA-B): $O^{6}$-POB-dGuo $(25,29)$; $O^{2}$-POB-dThd $(16,16) ; O^{2}$ POB-Cyt $(13,12)$. For each POB-DNA adduct, the ratio of adduct level in ctDNA-B to that in ctDNA-A was 3 , which was consistent with the higher amount of NNKOAc used in the reaction to form ctDNA-B than ctDNA-A.

\section{Characteristics of the method}

ctDNA-A and ctDNA-B were diluted with untreated calf thymus DNA and analyzed by the HPLC-ESI-MS/MS method. The results are shown in Figure 2A-D. All $\mathrm{R}^{2}$ values were 0.99 and the slopes ranged from 1.05 to 1.20 , supporting the accuracy of this method for quantitation of each POB-DNA adduct. The precision of the method was tested by analyzing seven aliquots at each of two adduct concentrations. Coefficients of variation were (\%, DNA concentration in fmol $/ \mathrm{mg}$ ) 7-POB-Gua $(10,35.5 ; 11,8.90) ; O^{6}$-POB-dGuo $(7,10.5 ; 14,2.62) ; O^{2}$-POB-dThd $(4,10.4 ; 11,2.08) ; O^{2}$-POB-Cyt $(5,43.6 ; 6,10.9)$. Sensitivity was determined by estimation of the limit of detection (LOD) of each adduct in $1 \mathrm{mg}$ DNA matrix with a signal-to-noise ratio of 3. LOD were $3 \mathrm{fmol}$ for 7-POB-Gua, $1 \mathrm{fmol}$ for $O^{6}$-POB-dGuo, 100 amol for $O^{2}$ - POBdThd, and 2 fmol for $O^{2}$-POB-Cyt. At least a 3 -fold improvement in sensitivity was achieved for pure standards in the absence of the DNA matrix. This implies matrix suppression of ionization in the MS analysis. Recoveries were determined based on recoveries of deuterated internal standards $(\mathrm{N}=24$ to 26$)$. The peak areas of the deuterated standards after the analysis procedure were compared to the standard curves constructed with the deuterated standards without undergoing the analysis procedure. Recoveries were $91 \pm 10 \%$ for 7-POB-Gua, $84 \pm$ $8 \%$ for $O^{6}$-POB-dGuo, $59 \pm 11 \%$ for $O^{2}$-POB-dThd, and $61 \pm 4 \%$ for $O^{2}$-POB-Cyt.

\section{Quantitation of POB-DNA adducts in NNK-treated rats}

About $0.5 \mathrm{mg}$ of each DNA sample was subjected to analysis and each measurement was carried out in duplicate. The amounts of internal standards were adjusted to ensure that peak area ratios of analyte/internal standard fell within the ranges of the calibration curves. POBDNA adducts were not detected in lung and liver DNA isolated from control rats (Figure 3A and 4A). The peaks eluting at the position of $O^{2}$-POB-dThd, the areas of which were $0.2 \%$ and $0.3 \%$ of [pyridine- $\left.\mathrm{D}_{4}\right] O^{2}$-POB-dThd, originated from the internal standard, as determined by control experiments in which the deuterated standards were added to calf thymus DNA.

Adducts were readily detected and quantified in the NNK-treated rats (Figure 3B and 4B). At both doses, relative adduct levels in lung and liver DNA (Figure 5A, B) had the same trend: 7 -POB-Gua $\approx O^{2}$-POB-dThd $>O^{2}$-POB-Cyt $>O^{6}$-POB-dGuo (see also Table 2 and 3 in 
Supporting Information). Consistent with the in vitro data (Figure 1), 7-POB-Gua was a major adduct detected in vivo. It accounted for $34 \%$ of total POB adduct levels in lung DNA in the low dose group and $35 \%$ in the high dose group. In liver DNA, the percentages of 7-POB-Gua were $35.4 \%$ of total POB adducts in the low dose group and $37.6 \%$ in the high dose group. In contrast to comprising about 25-29\% of total POB adducts in the NNKOAc-treated calf thymus DNA (Table 1 in Supporting Information), the percentages of $O^{6}$-POB-dGuo were only $9 \%$ in lung DNA and 0.3-0.4\% in liver DNA. The levels of $O^{6}$-POB-dGuo were 4-fold lower than 7-POB-Gua in lung DNA, and 90 to 130 -fold lower in liver DNA. The percentages of $O^{2}$-POBdThd of total POB adduct levels were 39-40\% in lung DNA and 35.1-38\% in liver DNA, and those of $O^{2}$-POB-Cyt were 16-17\% in lung DNA and 24-29.2\% in liver DNA. The dose ratio between the two NNK treatments was 4, and the ratios of individual adduct levels between the high dose and low dose groups were 2 for lung DNA and 3-5 for liver DNA, which was consistent with dose-dependent formation of these POB-DNA adducts from NNK in vivo.

Total average levels of POB-DNA adducts formed in the liver were higher than those in the lung $(15,100 \mathrm{fmol} / \mu \mathrm{mol} \mathrm{dGuo} \mathrm{versus} 4,180 \mathrm{fmol} / \mu \mathrm{mol} \mathrm{dGuo}$ for low dose; $48,600 \mathrm{fmol} / \mu \mathrm{mol}$ dGuo versus 7,730 fmol $/ \mu \mathrm{mol}$ dGuo for high dose). At the low dose, the levels of three adducts were 3-6 times higher in the liver than lung (Figure 6A-C). However, the amount of $O^{6}-\mathrm{POB}-$ dGuo was 9-fold higher in the lung than liver (Figure 6D). Similar results were seen in the high dose group (Figure 7A-D).

\section{Discussion}

NNN and NNK, upon metabolic activation, generate the DNA alkylating agent 6 with consequent formation of POB-DNA adducts (1). This pathway was established over 15 years ago (21), and has been quantified by measuring HPB-releasing DNA adducts (13). DNA samples were hydrolyzed with acid and the released HPB was quantified by gas chromatography-mass spectrometry after derivatization with pentafluorobenzoyl chloride (13). Using this assay, POB-DNA adduct formation was shown to be an important mechanism in NNN and NNK carcinogenesis in rodents (8-12). POB-DNA adducts very likely play an important role in tobacco carcinogenesis in smokers. Levels of HPB-releasing adducts were higher in lung DNA from smokers than non-smokers (13), and significantly higher levels of HPB-releasing adducts were found in human pulmonary DNA from lung cancer patients compared to controls (14). However, the assay of released HPB measured total levels of POBDNA adducts, which may include various nucleobase and phosphotriester adducts (22). Recently, four POB-DNA adducts were structurally characterized: $O^{6}$-POB-dGuo (3), 7-POBdGuo (6), $O^{2}$-POB-dThd (7) and $O^{2}$-POB-dCyd (7). 7-POB-dGuo and $O^{2}$-POB-dCyd were shown to release HPB upon neutral thermal hydrolysis, with the formation of the stable adducts 7-POB-Gua and $O^{2}$-POB-Cyt, respectively $(6,7)$. The availability of this structural information allows us to develop an assay to quantify these specific adducts rather than measuring released HPB as in previous studies, and thus further evaluate the role of each specific adduct in NNN and NNK carcinogenicity. There have been no previous reports of individual POB-DNA adduct levels in rats treated with NNN or NNK. The POB-DNA adducts may also have potential as biomarkers in studies of tobacco carcinogenesis and chemoprevention in humans.

The sensitive HPLC-ESI-MS/MS method described here was developed with modifications from our previous study (16). The enzymatic hydrolysis procedure was improved to decrease interferences resulting from incomplete DNA digestion. The procedure, which uses micrococcal nuclease, phosphodiesterase II and alkaline phosphatase, has been shown previously to completely digest DNA treated with radiolabelled NNKOAc (15). The HPLCESI-MS/MS method was further improved by monitoring the formation of the POB ion from the parent ion, resulting in five- and six-fold increases in sensitivity for $O^{2}$-POB-dGuo and $O^{6}$-POB-dThd, respectively, compared to our previous study (16). The accuracy and precision 
of the method were investigated using NNKOAc-modified DNA containing known amounts of adducts. Unlike pure POB-DNA adduct standards, modified DNA more closely mimics real DNA samples. The method was both accurate and precise. The method was also quite sensitive with detection limits of 0.1- 3 fmol adduct per mg DNA.

As shown in Figure 1, levels of 7-POB-Gua were the highest followed by $O^{6}$-POB-dGuo among the POB adducts in calf thymus DNA modified with NNKOAc. These results indicate that Gua in DNA has the highest reactivity toward pyridyloxobutylating agent 6 generated upon esterase activation of NNKOAc. Since 7-POB-Gua and $O^{2}$-POB-Cyt are partially released by neutral thermal hydrolysis during sample preparation from the unstable adducts, 7-POB-dGuo and $O^{2}$-POB-dCyd, respectively, levels of the initially formed 7-POB-dGuo and $O^{2}$-POB-dCyd are likely higher than those measured here. As shown in Scheme 1, neutral thermal hydrolysis of 7-POB-dGuo and $O^{2}$-POB-dCyd also produces HPB and deoxyribonucleosides, which were not measured here. The absolute levels are unknown since the absolute yields of 7-POB-Gua from 7-POB-dGuo and $O^{2}$-POB-Cyt from $O^{2}$-POB-dCyd are difficult to determine.

The in vitro data obtained in this study (Figure 1) were slightly different from our previous study (16), in which 7-POB-Gua accounted for $66 \%$ of all POB adducts, $O^{6}$ - POB-dGuo for $5 \%, O^{2}$-POB-dThd for $10 \%$, and $O^{2}$-POB-Cyt for $19 \%$. There are at least two explanations for these differences. First, a different enzymatic hydrolysis procedure was used in the previous study. The DNA may have been digested incompletely due to resistance of $O^{6}$-POB-dGuo to the enzymatic activity of snake venom phosphodiesterase I (23). Second, the previous study did not use deuterated internal standards for each adduct.

The formation of POB-DNA adducts in rats has been extensively studied by the measurement of HPB released upon acidic hydrolysis of DNA. Murphy et al compared levels of HPBreleasing adducts in rat lung and liver after four daily i.p. injections of different doses of radiolabelled NNK (24). At low doses of 15 to $150 \mu \mathrm{g} / \mathrm{kg} /$ day, levels of HPB released from lung DNA were higher than those from liver DNA, whereas at high doses of 600 to $5000 \mu \mathrm{g} /$ $\mathrm{kg} / \mathrm{day}, \mathrm{HPB}-\mathrm{releasing}$ DNA adduct levels in liver exceeded those in lung. Consistent with these results, Boysen et al found that HPB-releasing DNA adducts were significantly higher in lung than liver after treatment of rats with about $150 \mu \mathrm{g} / \mathrm{kg} / \mathrm{day}$ of NNK (12). Morse et al found higher levels of HPB released from liver DNA than lung DNA after treatment of rats with four consecutive daily s.c. doses of $600 \mu \mathrm{g} / \mathrm{kg} /$ day of NNK (9). Similar results were obtained by Peterson et al in rats treated with $0.8 \mathrm{mg} / \mathrm{kg}$ of radiolabelled NNK (25). In the current study, rats were given NNK at 5.2 or $20.7 \mathrm{mg} / \mathrm{kg} /$ day for 4 days by s.c. injection. Total levels of POB-DNA adducts were 4-6 times higher in liver DNA than in lung DNA, which is fully consistent with previous studies of HPB-releasing DNA adducts at high doses $(9,24,25)$. The dose-dependent tissue differences in total adduct levels may be due to different affinities of P450 enzymes in lung and liver for $\alpha$-methyl hydroxylation of NNK, or to other factors.

Consistent with the in vitro data, 7-POB-Gua levels were relatively high in vivo, accounting for about 34-38\% of all POB-DNA adducts. However, the levels of $O^{6}$-POB-dGuo changed dramatically from in vitro to in vivo. It accounted for $25-29 \%$ of all adducts in vitro, whereas the corresponding amounts were $9 \%$ in lung DNA and $0.3-0.4 \%$ in liver DNA. These results indicate that there is efficient cellular repair of $O^{6}$-POB-dGuo in vivo, especially in the liver. $O^{6}$-Alkylguanine-DNA-alkyltransferase $\left(\mathrm{AGT}^{1}\right.$ ) repairs $O^{6}$-POB-dGuo efficiently both in vitro and in vivo $(5,26-28)$. AGT is widely distributed in rat tissues such as liver, lung, esophagus, colon and kidney (29-31). AGT activity in liver is about 3 times higher than in lung. Different tissue distribution of AGT may explain the apparently more efficient repair of $O^{6}$-POB-dGuo in liver than lung. 
Comparison of adduct levels in the liver and lung DNA was very interesting. Except for $O^{6}$ POB-dGuo, levels of POB adducts were higher in liver DNA than in lung DNA in both dose groups (Figures 6 and 7). In contrast, the levels of $O^{6}$-POB-dGuo were 3-9 times higher in lung DNA than in liver DNA. The ratios of $O^{6}$-POB-dGuo levels between lung and liver DNA decreased with increasing dose, which may be due to AGT saturation. $O^{6}$-POB-dGuo is highly mutagenic in bacteria and human cells, causing $\mathrm{G}$ to $\mathrm{A}$ transitions (4). The apparent persistence of this mutagenic DNA adduct in rat lung, the main target tissue for NNK tumorigenicity, suggests that $O^{6}$-POB-dGuo plays an important role in NNK carcinogenicity in rats. This result is different from that reported in mice (27). A/J mice were treated with $\left[5-{ }^{3} \mathrm{H}\right] \mathrm{NNK}$ and $O^{6}$ POB-dGuo was detected in liver DNA but not in lung DNA. Formation and persistence of $\mathrm{O}^{6}$-methylguanine is a critical pathway for NNK-induced lung carcinogenesis in $\mathrm{A} / \mathrm{J}$ mice $(27,32)$.

The in vivo results with respect to $O^{2}$-POB-dThd are also of considerable interest. It is relatively abundant in both lung and liver DNA of NNK-treated rats. Its levels are comparable to those of 7-POB-Gua. It accounts for 35-38 \% of all adducts in liver DNA and 39-40\% in lung DNA, which may correspond to poor repair in vivo. In E. coli, 3-methyladenine DNA glycosylase II catalyzes the excision of $O^{2}$-alkylthymidines (33-35), whereas the repair of $O^{2}$ -

alkylthymidines in mammalian cells is not clearly understood. Besides $O^{6}$-POB-dGuo, $O^{2}$ POB-dThd is the only stable adduct among the four known POB-DNA adducts. While $O^{2}$ ethyl-dThd was shown to be mutagenic, causing $\mathrm{T}$ to A transversions $(36,37)$, the mutagenicity of $O^{2}$-POB-dThd is unknown. The HPLC-ESI-MS/MS method achieved high sensitivity for $O^{2}$-POB-dThd with a LOD of about $30 \mathrm{amol}$ for standard and $100 \mathrm{amol}$ in $1 \mathrm{mg}$ DNA. Current efforts are underway for detection and quantitation of $O^{2}$-POB-dThd and other POB-DNA adducts in smokers' DNA.

In summary, a sensitive HPLC-ESI-MS/MS method for quantitation of four POB-DNA adducts was developed and validated in this study. The method was applied to the analysis of DNA samples obtained from both in vitro and in vivo studies. In vitro, Gua was the most reactive nucleobase to the pyridyloxobutylating agent. In vivo, $O^{6}$-POB-dGuo appeared to be repaired, especially in liver. The results support the hypothesis that the mutagenic $O^{6}$-POBdGuo is critical for NNK-induced lung tumorigenesis in rats. $O^{2}$ - POB-dThd could be developed as a biomarker for tobacco carcinogenesis studies, on the basis of its relatively high abundance in vivo and its low LOD. The method described here is currently under evaluation for quantitation of POB-DNA adducts in human tissues.

\section{Supplementary Material}

Refer to Web version on PubMed Central for supplementary material.

\section{Acknowledgements}

The authors acknowledge Steven Carmella and Jon Bradley Hochalter for their valuable thoughts on method development. We also thank Patrick M. J. Kenney and Dr. Pramod Upadhyaya for their assistance in animal experiments and preparation of NNK, Guang Cheng and Yongli Shi for DNA isolation, Jana Scott for her help with synthesis of standards, and Bob Carlson for manuscript preparation. Dr. Stephen S. Hecht is an American Cancer Society Research Professor, supported in part by ACS grant RP-00-138. This work was supported by Grant CA-81301 from the National Cancer Institute.

\footnotetext{
${ }^{1}$ Abbreviations: AGT, $O^{6}$-alkylguanine-DNA-alkyltransferase; HPB, 4-hydroxy-1-(3- pyridyl)-1-butanone; HPLC-ESI-MS/MS, high performance liquid chromatography-electrospray ionization-tandem mass spectrometry; LOD, limit of detection; NNK, 4(methylnitrosamino)-1-(3-pyridyl)-1-butanone; NNKOAc, 4- (acetoxymethylnitrosamino)-1-(3-pyridyl)-1-butanone; NNN, $N^{\prime}$ nitrosonornicotine; $O^{2}$-POB-dCyd, $O^{2}$-[4-(3-pyridyl)-4-oxobut-1-yl]-2'-deoxycytidine; $O^{2}$-POB-Cyt, $O^{2}$-[4-(3-pyridyl)-4-oxobut-1-yl] cytosine; $O^{2}$-POB-dThd, $O^{2}$-[4-(3-pyridyl)-4-oxobut-1- yl]thymidine; $O^{6}$-POB-dGuo, $O^{6}$-[4-(3-pyridyl)-4-oxobut-1-yl]-2'deoxyguanosine; 7-POB-dGuo, 7-[4-(3-pyridyl)-4-oxobut-1-yl]-2'-deoxyguanosine; 7-POB-Gua, 7-[4-(3-pyridyl)-4-oxobut-1-yl] guanine; PCC, pyridinium chlorochromate; POB, 4-(3-pyridyl)-4-oxobut-1-yl; SRM, selected reaction monitoring.
} 


\section{References}

1. Hecht SS. Biochemistry, biology, and carcinogenicity of tobacco-specific $N$-nitrosamines. Chem Res Toxicol 1998;11:560-603.

2. International Agency on Research for Cancer. IARC Press Release, No. 154, November 16. 2004

3. Wang L, Spratt TE, Liu XK, Hecht SS, Pegg AE, Peterson LA. Pyridyloxobutyl adduct $O^{6}$-[4-oxo-4(3-pyridyl)butyl]guanine is present in 4-(acetoxymethylnitrosamino)-1-(3-pyridyl)-1-butanonetreated DNA and is a substrate for $O^{6}$-alkylhuanine-DNA alkyltransferase. Chem Res Toxicol 1997;10:562-567. [PubMed: 9168254]

4. Pauly GT, Peterson LA, Moschel RC. Mutagenesis of $O^{6}$-[4-oxo- 4-(3-pyridyl)butyl]guanine in Escherichia coli and human cells. Chem Res Toxicol 2002;15:165-169. [PubMed: 11849042]

5. Mijal RS, Loktionova NA, Vu CC, Pegg AE, Peterson LA. $O^{6}$-[4-Oxo-4-(3-pyridyl)butyl]guanine adducts contribute to the mutagenic properties of pyridyloxoxbutylating agents. Chem Res Toxicol 2005;18:1619-1625. [PubMed: 16533027]

6. Wang M, Cheng G, Sturla SJ, Shi Y, McIntee EJ, Villalta PW, Upadhyaya P, Hecht SS. Identification of adducts formed by pyridyloxobutylation of deoxyguanosine and DNA by 4(acetoxymethylnitrosamino)-1-(3-pyridyl)-1-butanone, a chemically activated form of tobacco specific carcinogens. Chem Res Toxicol 2003;16:616-626. [PubMed: 12755591]

7. Hecht SS, Villalta PW, Sturla SJ, Cheng G, Yu N, Upadhyaya P, Wang M. Identification of $O^{2}$ substituted pyrimidine adducts formed in reactions of 4-(acetoxymethylnitrosamino)-1-(3-pyridyl)-1butanone and 4- (acetoxymethylnitrosamino)-1-(3-pyridyl)-1-butanol with DNA. Chem Res Toxicol 2004;17:588-597. [PubMed: 15144215]

8. Trushin N, Rivenson A, Hecht SS. Evidence supporting the role of DNA pyridyloxobutylation in rat nasal carcinogenesis by tobacco-specific nitrosamines. Cancer Res 1994;54:1205-1211. [PubMed: 8118807]

9. Morse MA, Wang CX, Stoner GD, Mandal S, Conran PB, Amin SG, Hecht SS, Chung FL. Inhibition of 4-(methylnitrosamino)-1-(3-pyridyl)-1-butanone-induced DNA adduct formation and tumorigenicity in lung of F344 rats by dietary phenethyl isothiocyanate. Cancer Res 1989;49:549553. [PubMed: 2910476]

10. Staretz ME, Foiles PG, Miglietta LM, Hecht SS. Evidence for an important role of DNA pyridyloxobutylation in rat lung carcinogenesis by 4-(methylnitrosamino)-1-(3-pyridyl)-1-butanone: effects of dose and phenethyl isothiocyanate. Cancer Res 1997;57:259-266. [PubMed: 9000565]

11. Sticha KRK, Kenney PMJ, Boysen G, Liang H, Su X, Wang M, Upadhyaya P, Hecht SS. Effects of benzyl isothiocyanate and phenethyl isothiocyanate on DNA adduct formation by a mixture of benzo [a]pyrene and 4-(methylnitrosamino)-1-(3-pyridyl)-1-butanone in A/J mouse lung. Carcinogenesis 2002;23:1433-1439. [PubMed: 12189184]

12. Boysen G, Kenney PMJ, Upadhyaya P, Wang M, Hecht SS. Effects of benzyl isothiocyanate and 2phenethyl isothiocyanate on benzo[a]pyrene and 4-(methylnitrosamino)-1-(3-pyridyl)-1-butanone metabolism in F-344 rats. Carcinogenesis 2003;24:517-525. [PubMed: 12663513]

13. Foiles PG, Akerkar SA, Carmella SG, Kagan M, Stoner GD, Resau JH, Hecht SS. Mass spectrometric analysis of tobacco-specific nitrosamine-DNA adducts in smokers and nonsmokers. Chem Res Toxicol 1991;4:364-368. [PubMed: 1912321]

14. Schlöbe D, Hölze D, Richter E, Tricker AR. Determination of tobacco-specific nitrosamine hemoglobin and lung DNA adducts. Proc Am Assoc Canc Res 2002;43:346.

15. Thomson NM, Mijal RS, Ziegel R, Fleischer NL, Pegg AE, Tretyakova NY, Peterson LA. Development of a quantitative liquid chromatography/electrospray mass spectrometric assay for a mutagenic tobacco specific nitrosamine-derived DNA adduct, $O^{6}$-[4-oxo-4-(3-pyridyl)butyl]-2'deoxyguanosine. Chem Res Toxicol 2004;17:1600-1606. [PubMed: 15606135]

16. Sturla SJ, Scott J, Lao Y, Hecht SS, Villalta PW. Mass spectrometric analysis of relative levels of pyridyloxobutylation adducts formed in the reaction of DNA with a chemically activated form of the tobacco-specific carcinogen 4-(methylnitrosamino)-1-(3-pyridyl)-1-butanone. Chem Res Toxicol 2005;18:1048-1055. [PubMed: 15962940] 
17. Lin JM, Amin S, Murphy SE, Solomn JJ, Hecht SS. Synthesis of [3, 3-D 2 ]4-hydroxy-1-(3-pyridyl)-1butanone, an internal standard for analysis of tobacco-specific nitrosamine hemoglobin and DNA adducts. J Labelled Comp Radiopharma 1992;23:285-292.

18. Shi DF, Wheelhouse RT, Sun D, Hurley LH. Quadruplex-interactive agents as telomerase inhibitors: synthesis of porphyrins and structure-activity relationship for the inhibition of telomerase. J Med Chem 2001;44:4509-4523. [PubMed: 11741471]

19. Spratt TE, Peterson LA, Confer WL, Hecht SS. Solvolysis of model compounds for $\alpha$-hydroxylation of $N^{\prime}$-nitrosonornicotine and 4-(methylnitrosamino)-1-(3-pyridyl)-1-butanone: evidence for a cyclic oxonium ion intermediate in the alkylation of nucleophiles. Chem Res Toxicol 1990;3:350-356. [PubMed: 2133084]

20. Wang M, Yu N, Chen L, Villalta PW, Hochalter JB, Hecht SS. Identification of an acetaldehyde adduct in human liver DNA and quantitation as $N^{2}$-ethyldeoxyguanosine. Chem Res Toxicol 2006;19ASAP

21. Hecht SS, Spratt TE, Trushin N. Evidence for 4-(3-pyridyl)-4-oxobutylation of DNA in F344 rats treated with the tobacco-specific nitrosamines 4-(methylnitrosamino)-1-(3-pyridyl)-1-butanone and $N^{\prime}$-nitrosonornicotine. Carcinogenesis 1988;9:161-165. [PubMed: 3335041]

22. Haglund J, Henderson AP, Golding B, Törnqvist M. Evidence for phosphate adducts in DNA from mice treated with 4-( $N$-methyl- $N$-nitrosamino)-1-(3-pyridyl)-1-butanone (NNK). Chem Res Toxicol 2002;15:773-779. [PubMed: 12067244]

23. Park S, Seetharaman M, Ogdie A, Ferguson D, Tretyakova N. 3'-Exonuclease resistance of DNA oligodeoxynucleotides containing $O^{6}$-[4-oxo-4-(3-pyridyl)butyl]guanine. Nucleic Acids Res 2003;31:1984-1994. [PubMed: 12655016]

24. Murphy SE, Palomino A, Hecht SS, Hoffmann D. Dose-response study of DNA and hemoglobin adduct formation by -(methylnitrosamino)-1-(3- pyridyl)-1-butanone in F344 rats. Cancer Res 1990;50:5446-5452. [PubMed: 2386949]

25. Peterson LA, Mathew R, Murphy SE, Trushin N, Hecht SS. In vivo and in vitro persistence of pyridyloxobutyl DNA adducts from 4-(methylnitrosamino)-1-(3-pyridyl)-1-butanone. Carcinogenesis 1991;12:2069-2072. [PubMed: 1934291]

26. Wang L, Spratt TE, Pegg AE, Peterson LA. Synthesis of DNA oligonucleotides containing sitespecifically incorporated $O^{6}$-[4-oxo-4-(3-pyridyl)butyl]guanine and their reaction with $O^{6}$ alkylguanine-DNA alkyltransferase. Chem Res Toxicol 1999;12:127-131. [PubMed: 10027788]

27. Thomson NM, Kenney PMJ, Peterson LA. The pyridyloxobutyl DNA adduct, $O^{6}$-[4-oxo-4-(3pyridyl)butyl]guanine, is present in tissues from 4-(methylnitrosamino)-1-(3-pyridyl)-1-butanonetreated A/J mice. Chem Res Toxicol 2003;16:1-6. [PubMed: 12693024]

28. Mijal RS, Thomson NM, Fleisher NL, Pauly GT, Moschel RC, Kanugula S, Fang Q, Pegg AE, Peterson LA. The repair of the tobacco-specific nitrosamine derived adduct $O^{6}$-[4-oxo-4-(3-pyridyl) butyl]guanine by $O^{6}$-alkylguanine-DNA alkyltransferase variants. Chem Res Toxicol 2004; 17:424434. [PubMed: 15025514]

29. Grafstrom RC, Pegg AE, Trump BF, Harris CC. $O^{6}$-alkylguanine-DNA alkyltransferas activity in normal human tissues and cells. Cancer Res 1984;44:2855-2857. [PubMed: 6722814]

30. Pegg AE. Properties of the $O^{6}$-alkylguanine-DNA repair system of mammalian cells. International Agency for Research on Cancer (IARC) Sci Publ 1984;57:575-580.

31. Jun GJ, Ro JY, Kim MH, Park GH, Park WK, Magee PN, Kim S. Studies on the distribution of $O^{6}$ methylguanine-DNA methyltransferase in rat. Biochem Pharmcol 1986;35:377-384.

32. Peterson LA, Hecht SS. $O^{6}$-Methylguanine is a critical determinant of 4-(methylnitrosamino)-1-(3pyridyl)-1-butanone tumorigenesis in A/J mouse lung. Cancer Res 1991;51:5557-5564. [PubMed: 1913675]

33. O'Brien PJ, Ellenberger T. The Escherichia coli 3-methyladenine DNA glycosylase AlkA has a remarkably versatile active site. J Biol Chem 2004;279:26876-26884. [PubMed: 15126496]

34. McCarthy TV, Karran P, Lindahl T. Inducible repair of $O$-alkylated DNA pyrimidines in Escherichia coli. EMBO J 1984;3:545-550. [PubMed: 6370685]

35. Brent TP, Dolan ME, Fraenkel-Conrat H, Hall J, Karran P, Laval F, Margison GP, Montesano R, Pegg AE, Potter PM, Singer B, Swenberg JA, Yarosh DB. Repair of $O$-alkylpyrimidines in 
mammalian cells: a present consensus. Proc Natl Acad Sci USA 1988;85:1759-1762. [PubMed: 3162305]

36. Grevatt PC, Solomon JJ, Bhanot OS. In vitro mispairing specificity of $O^{2}$-ethylthymidine. Biochemistry 1992;31:4181-4188. [PubMed: 1567865]

37. Bhanot OS, Grevatt PC, Donahue JM, Gabrielides C, Solomon JJ. In vitro DNA replication implicates $O^{2}$-ethyldeoxythymidine in transversion mutagenesis by ethylating agents. Nucleic Acids Res 1992;20:587-594. [PubMed: 1741292] 


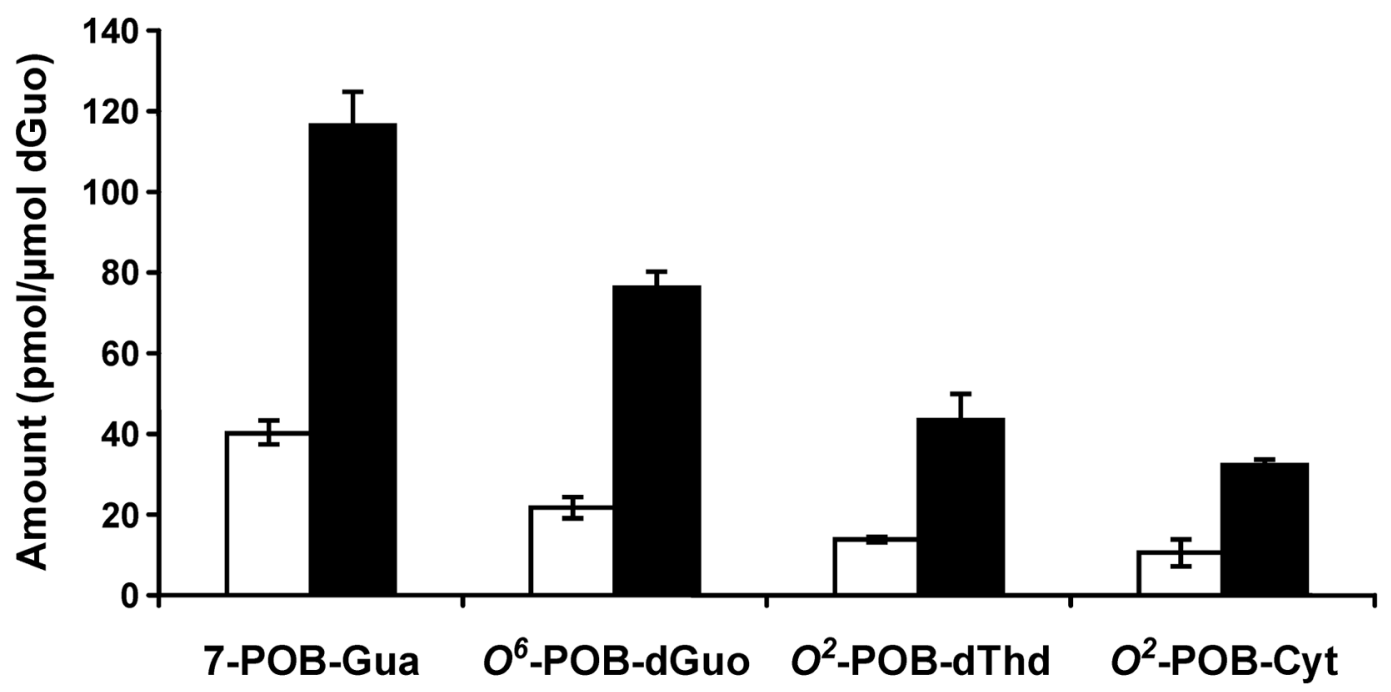

Figure 1.

Levels of POB-DNA adducts in NNKOAc-treated calf thymus DNA. Open bars: ctDNA-A; solid bars: ctDNA-B. Each value is the mean \pm S.D. of at least three measurements. 

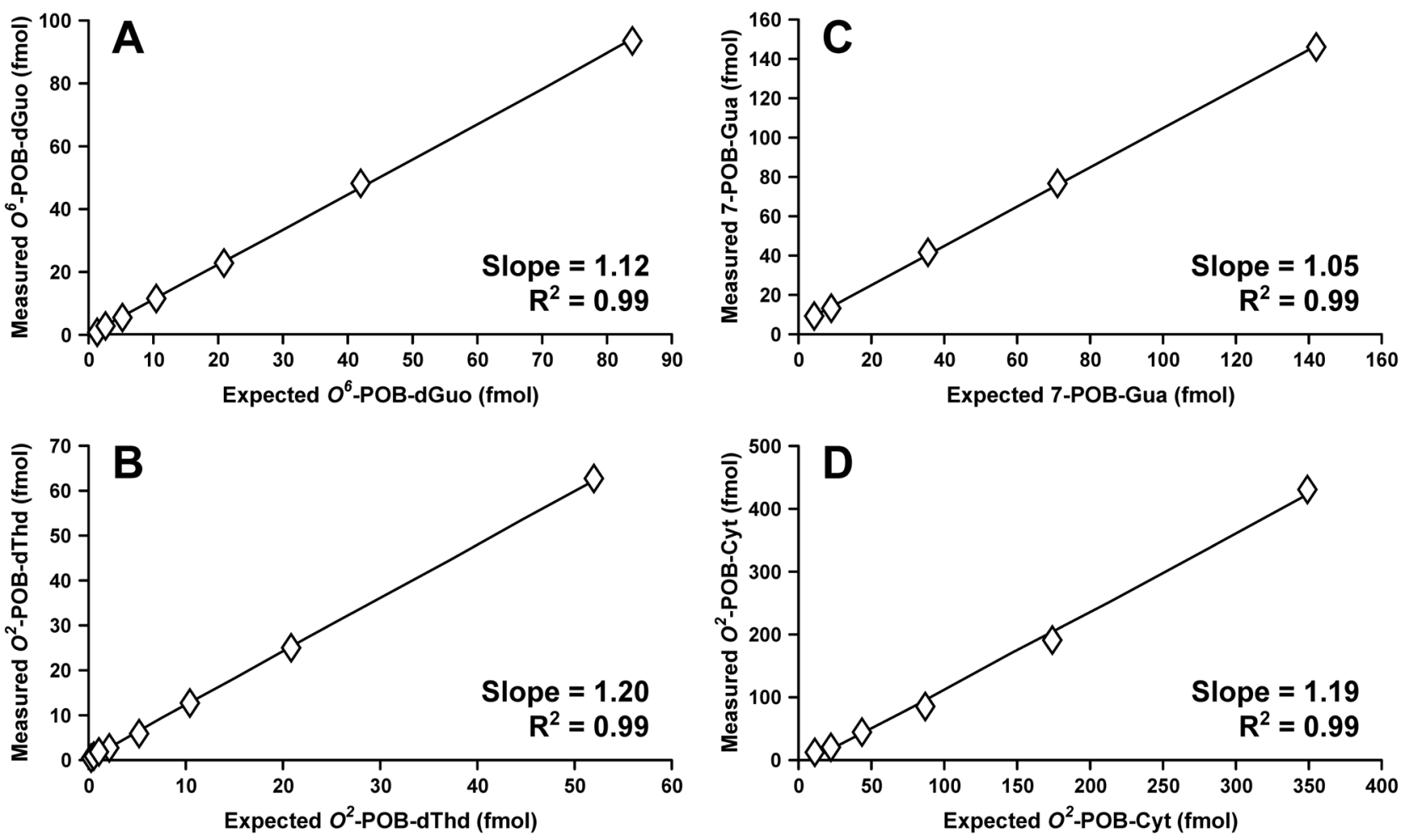

Figure 2.

Correlations between expected and measured levels of POB-DNA adducts in NNKOAc-treated calf thymus DNA (A) $O^{6}$-POB-dGuo; (B) $O^{2}$-POB-dThd; (C) 7-POB-Gua; (D) $O^{2}$-POB-Cyt. Each value is the mean of duplicate measurements of diluted ctDNA-A or ctDNA-B. The ranges of expected levels of POB-DNA adducts were: $1.31-83.83 \mathrm{fmol}$ for $O^{6}$-POB-dGuo; 0.26-51.95 fmol for $O^{2}$-POB-dThd; 4.45-142 fmol for 7-POB-Gua; and 10.91-349 fmol for $O^{2}$-POB-Cyt. The amounts of added internal standards were: $49.95 \mathrm{fmol}$ [pyridine- $\mathrm{D}_{4}$ ] $O^{6}$ POB-dGuo, 45.57 fmol [pyridine- $\mathrm{D}_{4}$ ] $O^{2}$-POB-dThd, $80 \mathrm{fmol}$ [pyridine- $\mathrm{D}_{4}$ ]7-POB-Gua, and $136.1 \mathrm{fmol}\left[\right.$ pyridine- $\mathrm{D}_{4} \mathrm{O}^{2}$-POB-Cyt. 
A

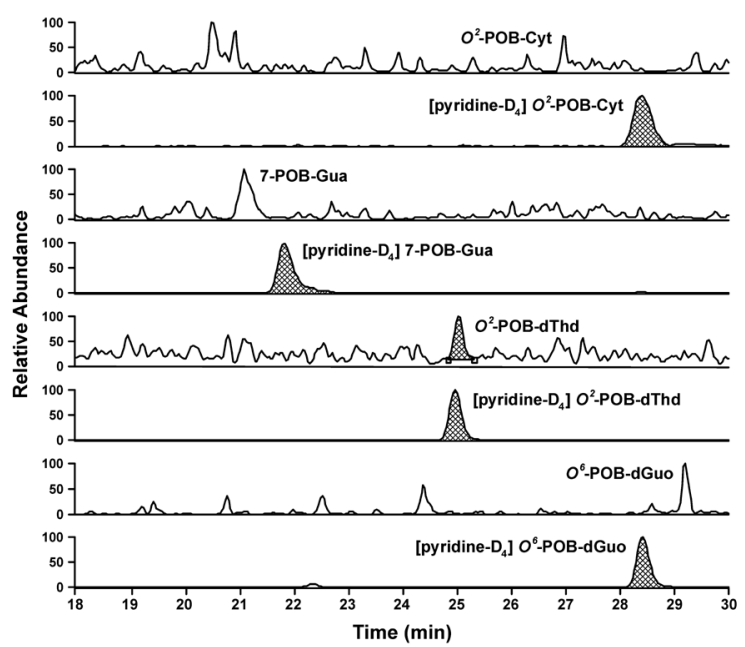

B

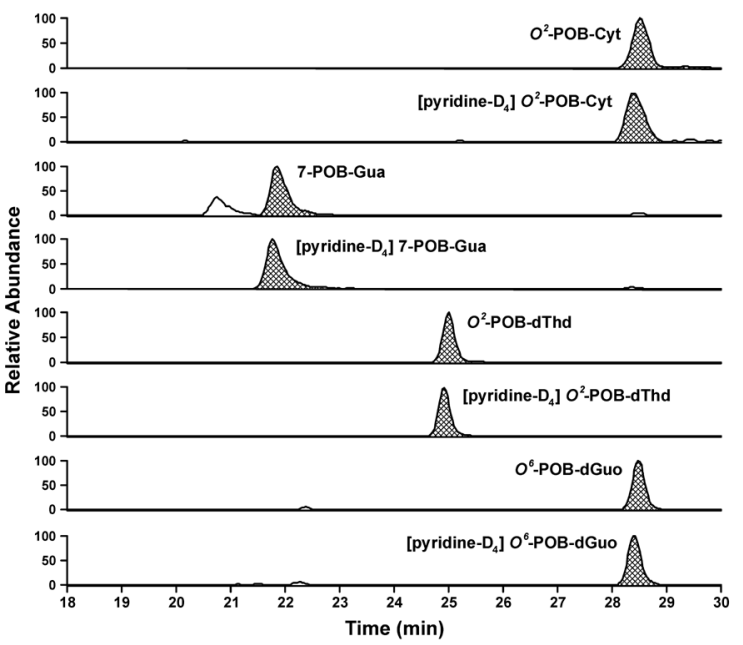

Figure 3.

SRM chromatograms obtained upon analysis of rat lung DNA isolated from (A) control group and (B) low dose NNK-treated group. Individual POB-DNA adducts or internal standards were monitored as indicated on each channel. In Figure 3A, the peak eluting at the position of $O^{2}$ POB-dThd, the area of which is $0.2 \%$ of [pyridine- $\left.\mathrm{D}_{4}\right] \mathrm{O}^{2}$ - POB-dThd, originates from the internal standard. 

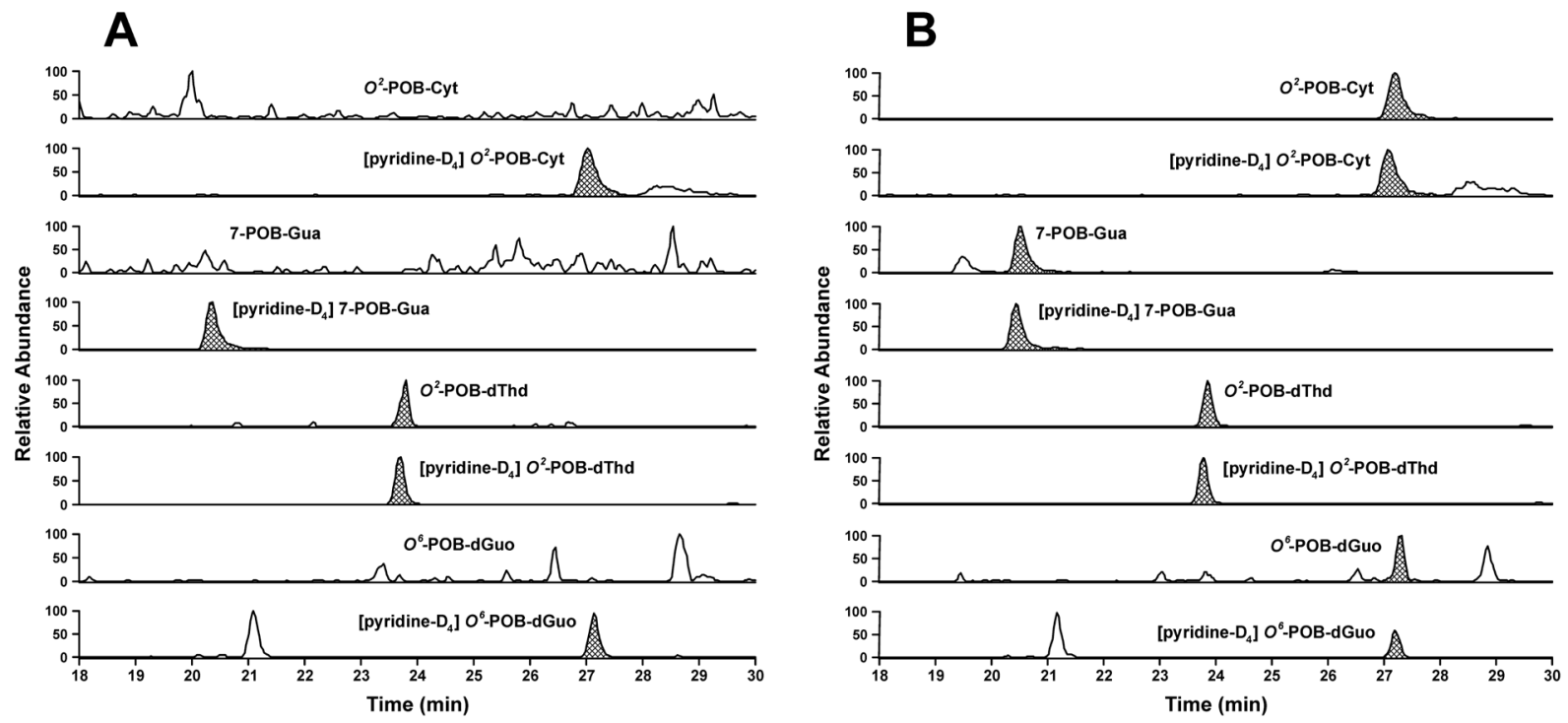

Figure 4.

SRM chromatograms obtained upon analysis of rat liver DNA isolated from (A) control group and (B) low dose NNK-treated group. Individual POB-DNA adducts or internal standards were monitored as indicated on each channel. In Figure 4A, The peak eluting at the position of $O^{2}$ POB-dThd, the area of which is $0.3 \%$ of [pyridine- $\left.\mathrm{D}_{4}\right] O^{2}-\mathrm{POB}-\mathrm{dThd}$, originates from the internal standard. 

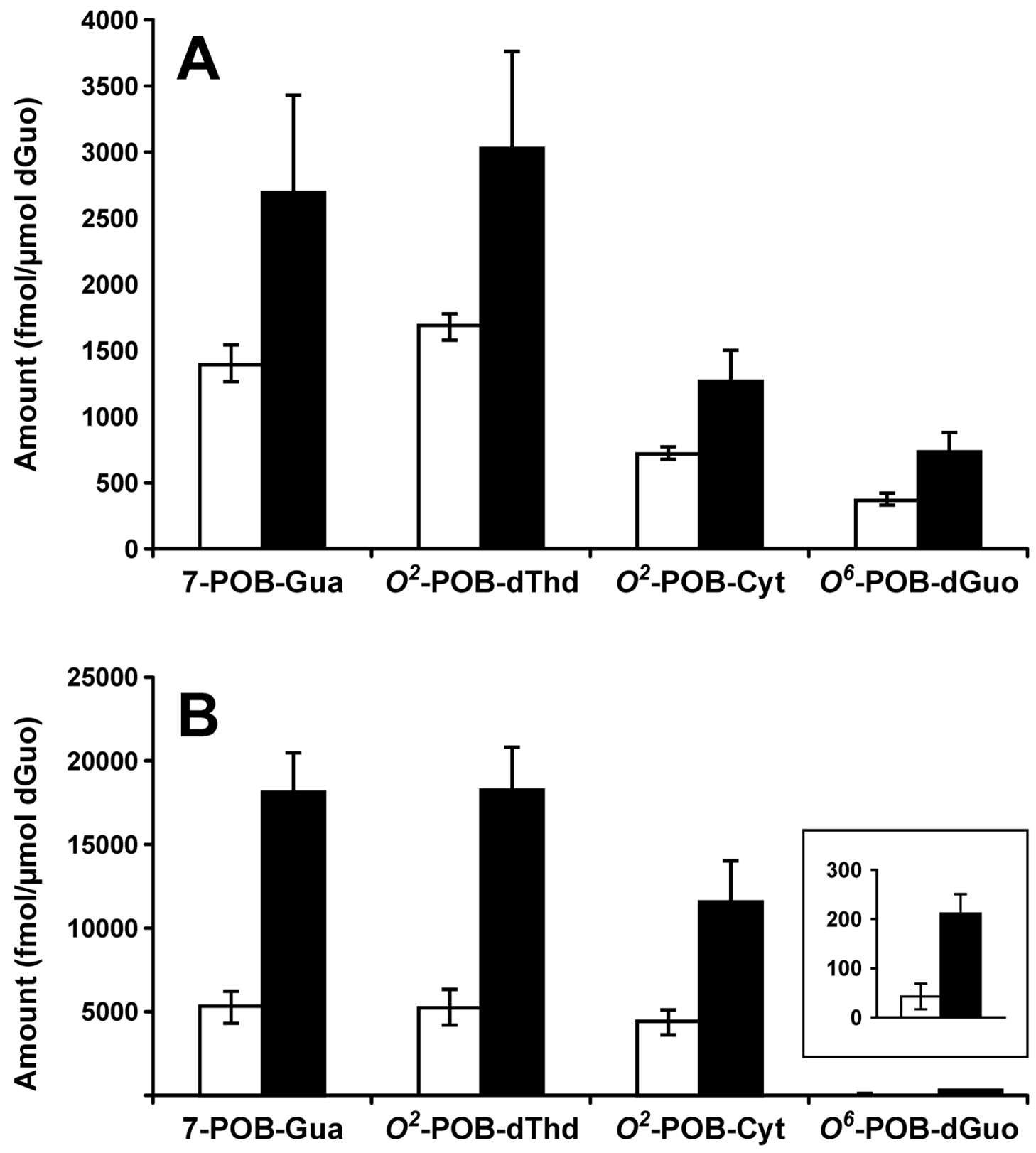

Figure 5.

Levels of POB-DNA adducts in (A) lung and (B) liver DNA of NNK-treated rats. Inset: plot of $O^{6}$-POB-dGuo on a different scale. Open bars: low dose; solid bars: high dose. Each value is the mean \pm S.D. of duplicate measurements of each DNA sample isolated from five rats per group. 

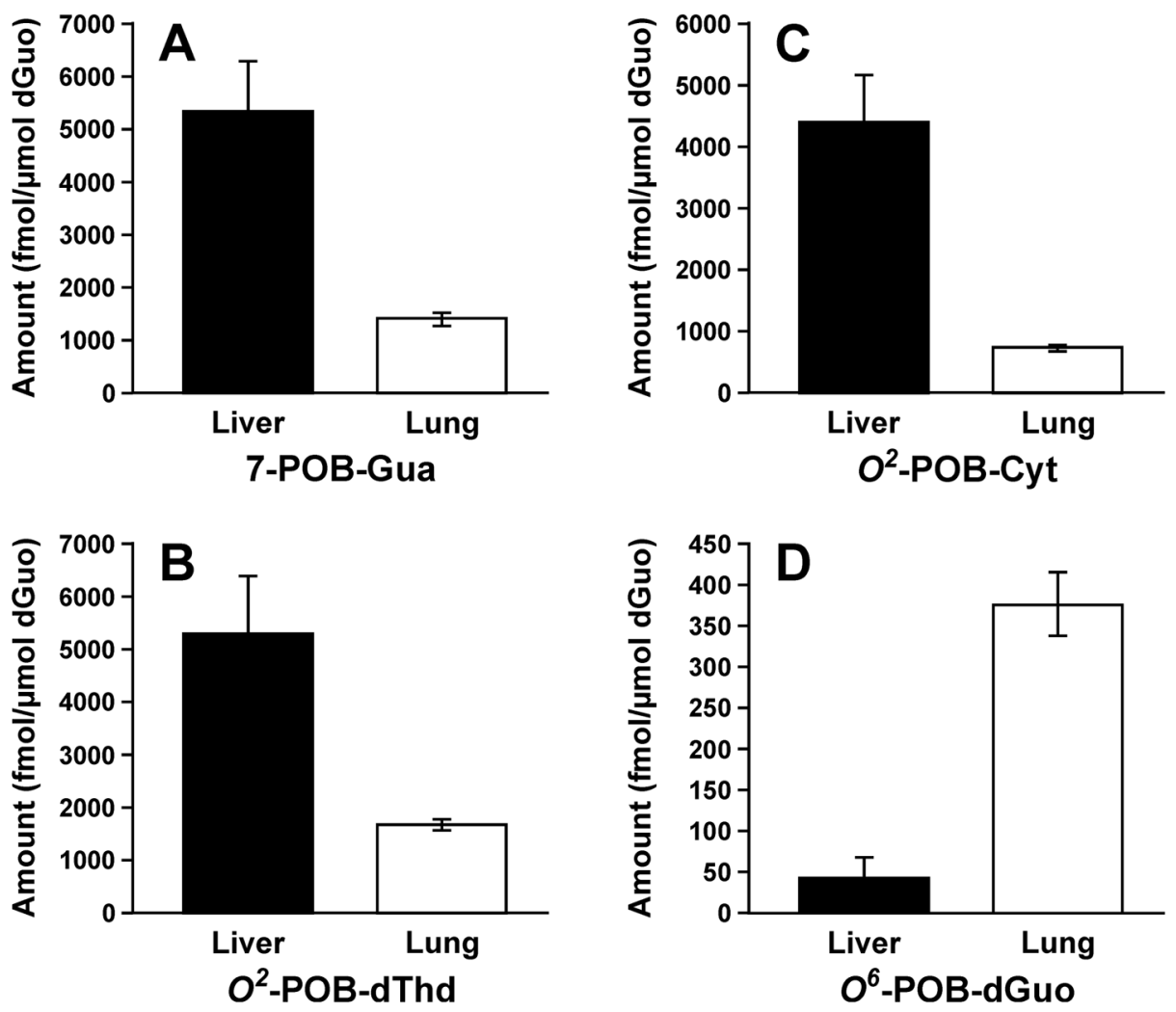

Figure 6.

Comparisons of POB-DNA adduct levels in liver and lung DNA of NNK-treated rats in the low dose group $\left(0.025 \mathrm{mmol} / \mathrm{kg}\right.$ bw per day for four days). (A) 7-POB-Gua; (B) $O^{2}$-POBdThd; (C) $O^{2}$-POB-Cyt; (D) $O^{6}$-POB-dGuo. Open bars: adduct levels in lung DNA; solid bars: adduct levels in liver DNA. Each value is the mean \pm S.D. of duplicate measurements of individual DNA sample isolated from each of 5 rats in the low dose group. 

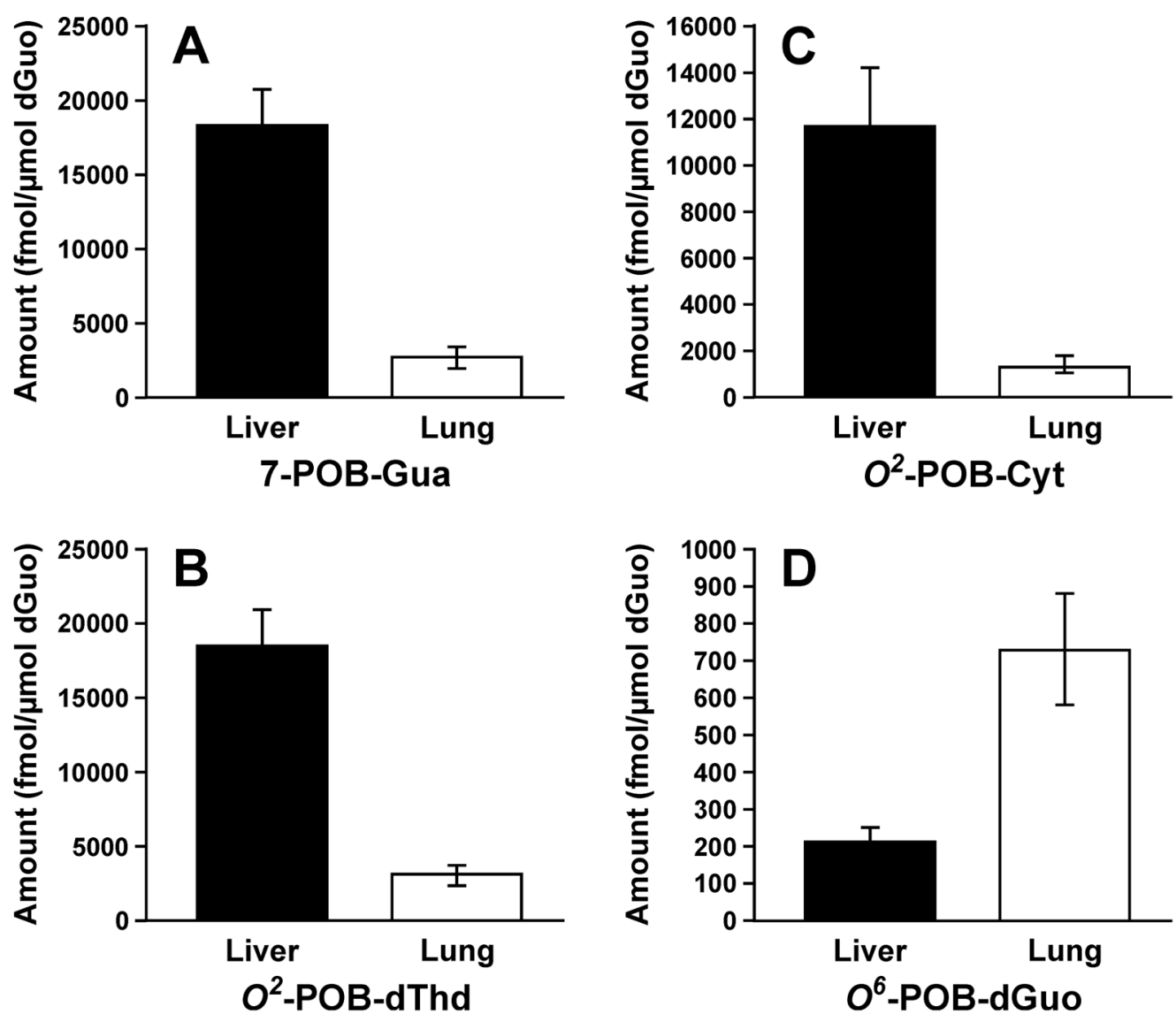

Figure 7.

Comparisons of POB-DNA adduct levels in liver and lung DNA of NNK-treated rats in the high dose group $\left(0.1 \mathrm{mmol} / \mathrm{kg}\right.$ bw per day for four days). (A) 7-POB-Gua; (B) $O^{2}$-POB-dThd; (C) $O^{2}$-POB-Cyt; (D) $O^{6}$-POB-dGuo. Open bars: adduct levels in lung DNA; solid bars: adduct levels in liver DNA. Each value is the mean \pm S.D. of duplicate measurements of individual DNA sample isolated from each of 5 rats in the high dose group. 


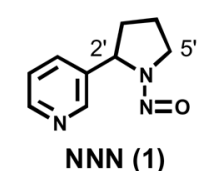<smiles>CN(CCCC(=O)c1cccnc1)N=O</smiles>

NNK (2)<smiles>C[13CH3]</smiles><smiles>CC1(O)CCCN1N=O</smiles>

4

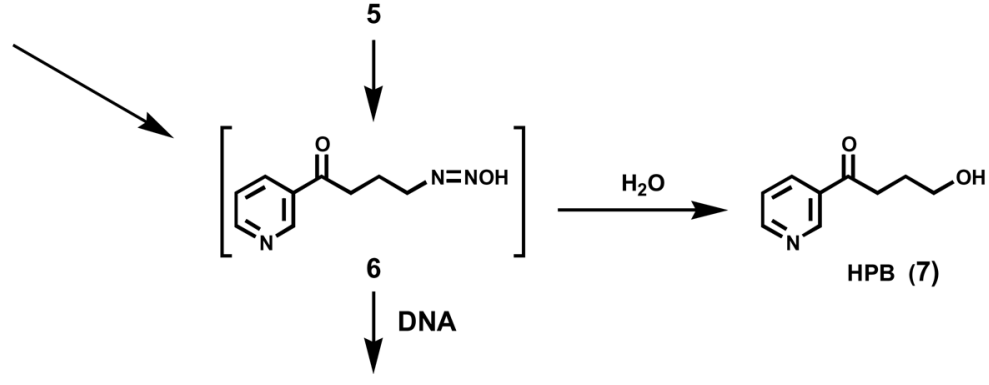<smiles>O=NN(CO)CCCC(=O)c1cccnc1</smiles>

NNKOAC (3)<smiles>O=NN(CO)CCCC(=O)c1cccnc1</smiles>

NNOA

Pyridyloxobutyl (POB) Adducts<smiles>CCCC(=O)c1cccnc1</smiles><smiles></smiles><smiles></smiles><smiles>Cc1cn(Cc2ccccc2)c(OCCC(=O)c2cccnc2)nc1=O</smiles>

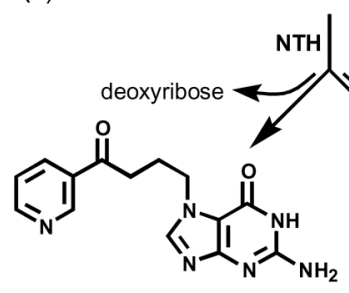

7-POB-Gua (12) 